\author{
비강측벽에 발생한 다형성 선종 1 예 \\ 가톨릭대학교 의과대학 이비인후과학교실 \\ 황성재 · 박용진 · 송기영 · 성용해
}

\title{
A Case of Pleomorphic Adenoma of the Lateral Nasal Wall
}

\author{
Sung-Jae Hwang, MD, Yong-Jin Park, MD, Ki-Young Song, MD and Yong-Hae Sung, MD \\ Department of Otolaryngology-Head and Neck Surgery, College of Medicine, \\ Catholic University of Korea, Seoul, Korea
}

\begin{abstract}
- ABSTRACT -
Pleomorphic adenoma most commonly affects the major salivary gland, the minor salivary glands affected rarely. Although the nasal cavity has numerous serous and mucous glands, pleomorphic adenoma at this site is unusual. Fewer than $10 \%$ of the intranasal pleomorphic adenoma were noted to arise from the lateral nasal wall, with the rest originating from the septum. The authors presented a very rare case of pleomorphic adenoma of the lateral nasal wall successfully treated by endoscopic resection. (J Clinical Otolaryngol 2005;16:157-159)
\end{abstract}

KEY WORDS : Pleomorphic adenoma $\cdot$ Nasal cavity.

\section{서 론}

다형성 선종은 타액선에서 발생하는 양성 종양 중 가 장 빈도가 높은 종양으로, 대부분이 주타액선에서 발생 하며 8 10\% 만 소타액선에서 발생하는 것으로 알려져 있다. 상기도의 소타액선에서 발생하는 경우 비강, 상악 동, 비인두의 순서로 발생한다. ${ }^{1)}$ 비강내에서는 비중격에 호발하며, 비강측벽에서 기원한 다형성 선종은 매우 드 물어 국내에서는 아직 보고된 바가 없다.

저자들은 비강측벽에 발생한 다형성 선종 1 예를 경험 하고 내시경적 제거술을 시행하여 성공적으로 치유하였 기에 문헌고찰과 함께 보고하는 바이다.

논문접수일 : 2005년 3월 27일

심사완료일 : 2005년 4월 29일

교신저자 : 박용진, 442- 060 경기도 수원시 팔달구 지동

93 가톨릭대학교 의과대학 이비인후과학교실

전화 :(031) 249- 8203. 전송 :(031) 257- 3752

E- mail : yp@ catholic.ac.kr

\section{증 례}

환자는 53세 남자로 십수년간 지속된 좌측 비폐색을 주소로 2002년 4월 23일 내원하였다. 재채기 및 좌측 후각기능 저하도 호소하였으며 가족력이나 과거력에서 특 이소견은 없었다. 비내시경 검사에서 좌측 비전정 직후 방에서 분홍색을 띤 불규칙한 표면의 부드러운 종괴가 비강 전체를 막고 있었다(Fig. 1). 비강 측벽에서 기시 하였으며 궤양이나 출혈 소견은 보이지 않았다. 임상 검 사 소견에서 혈액검사, 뇨검사, 생화학검사, 심전도 검사 등은 정상이었다. 전산화 단층촬영 소견에서 $2.0 \times 1.5 \times$ $1.0 \mathrm{~cm}$ 크기의 주변조직과 잘 경계지워진 달걀형의 종 괴가 좌측 전비강내에서 관찰되었으며, 주변 골파괴 소 견은 보이지 않았다. 조영제 주입 후 종괴 경계부에 다 소 조영증가가 관찰되었다Fig. 2). 수술 전 시행한 병 리조직 검사에서 다형성 선종에 합당한 소견이 보였다.

환자는 2002년 6월 12일 전신마취하에 내시경수술로 주변 정상조직을 포함한 종괴를 절제하였다. 종괴는 좌 


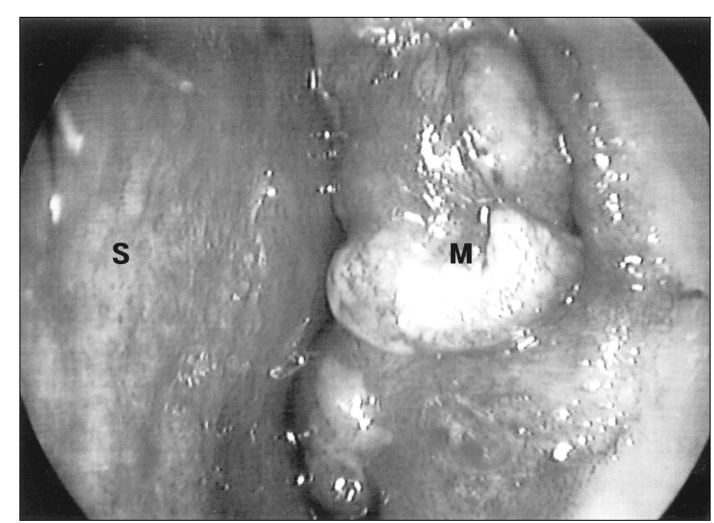

Fig. 1. Preoperative endoscopic finding. An irregular surfaced pinkish mass arising from the left lateral nasal wall just behind the nasal vestibule is filling the anterior nasal cavity ( $S$ : nasal septum, $M$ : mass).

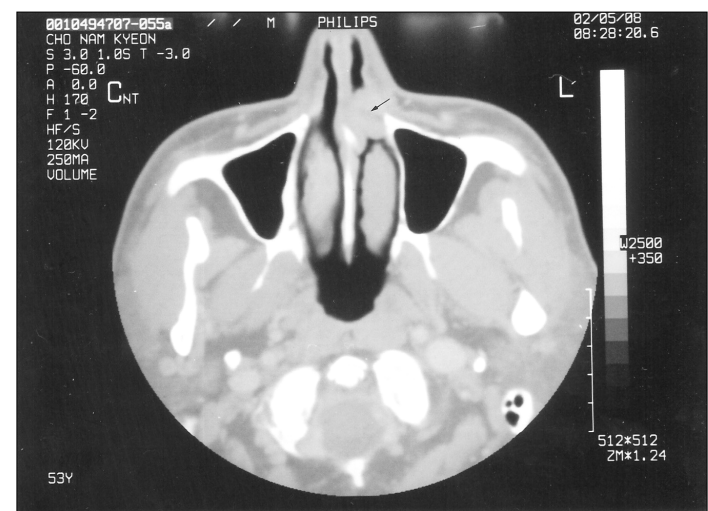

Fig. 2. Preoperative axial view of PNS CT. The well circumscribed mass with somewhat marginal enhancement is confined to the anterior left nasal cavity.

측 하비갑개 전방의 비강외벽에서 기인하고 있었으며, 비 갑개나 비중격과의 유착은 없었다. 절제된 조직은 $2.0 x$ $1.5 \times 1.0 \mathrm{~cm}$ 크기의 노란색 종괴로 출혈이나 궤양 등 악성으로 의심되는 소견은 없었다 Fig. 3). 절단면은 노 란색과 흰색의 혼합된 병소가 관찰되었다. 조직학적 소 견은 풍부한 점액성의 간질 사이에 선상구조를 이루는 상피세포가 관찰되었으며, 세포질이 다소 높은 부분도 관 찰되었다. 이형성 세포 등의 악성을 의심할 만한 소견은 보이지 않았다 (Fig. 4).

수술 후 항생제 등의 보존적 치료를 하였으며, 별다 른 문제없이 술 후 2병일에 퇴원하였다. 수술 후 2년 6 개월 동안 비내시경 검사로 추적 관찰한 결과 재발의

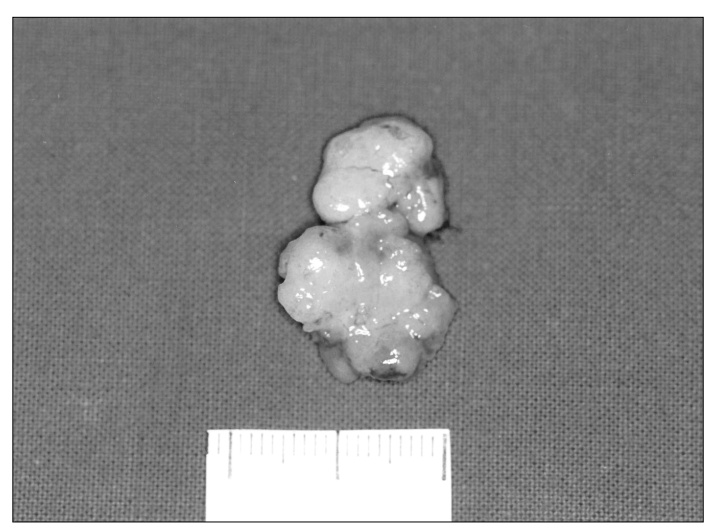

Fig. 3. Gross specimen finding. A yellowish mass measuring $2.0 \times 1.5 \times 1.0 \mathrm{~cm}$ is seen.

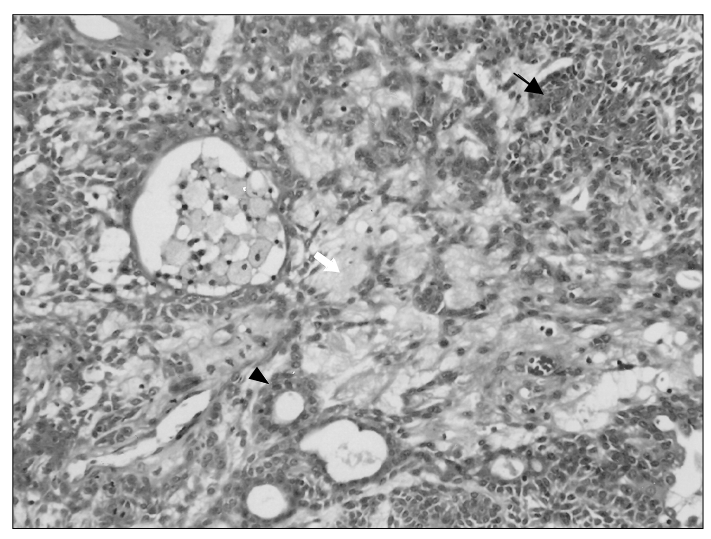

Fig. 4. Histopathologic finding of the mass showing abundant myxoid stroma with interspersed island of epithelial cells. white arrow : myxoid stroma, black arrow : epithelial cells, arrow head : ductal epithelial cell ( H \& E stain, $\times 200$ ).

소견은 없었다.

\section{고 찰}

다형성 선종은 경계가 분명한 양성 종양으로 주로 주 타액선에서 발생하며, 상기도 등의 소타액선에서 발생하 는 경우는 드물다. 상피성 요소와 간엽성 요소가 이중 기 원을 하는 종양으로, 상기도 중에서는 비강에서 가장 많 이 발생하며, 상악동, 비인두 순이다. 비강내 다형성 선 종은 $10 \%$ 미만이 외측벽에서 발생하며, 나머지는 비중 격에서 발생한다. ${ }^{2)}$ 이와 같은 보고는 비강내 소타액선이 주로 외측벽과 비갑개에 분포되어 있다는 해부학적 사 
실과 일치하지 않는다. 이에 대한 설명으로 여러 가지 발병기전이 제시되고 있으나 아직까지 확실하게 밝혀진 것은 없다.

비강내 다형성 선종은 대부분 30대와 60 대 사이에 서 발생하며 여자에서 조금 더 많이 발생한다. 주된 증 상은 일측성 비폐색이나 비충만감, 비출혈 등의 증상도 있을 수 있으며 증상이 없는 경우도 있다. 비내시경 소 견에서 종괴는 전형적으로 쉽게 출혈하는 균질의 외장 성 용성 구조를 보이며 색깔은 회백색에서 회분홍색까 지 다양하다. ${ }^{1-3)}$

다형성 선종의 전산화 단층 촬영 소견은 비특이적으로, 비강내의 잘 경계지워진 연조직성의 팽창성 성장을 하 는 종물의 형태로 관찰된다. 병의 만성 경과로 인해 주 변 골조직의 변성이 나타나기도 하며, 석회화는 드물다. 이러한 소견이외에도 악성 종양을 의심해볼 수 있는 주 위 구조물의 골파괴 소견을 보이기도 한다. ${ }^{4)}$ 전산화 단 층 촬영 결과 비내 종물이 비균질하게 조영 증강되거나 주위 조직과의 경계가 명확하지 않은 소견을 보였던 경 우 조직검사에서 악성 종양으로 판명된 보고도 있다. ${ }^{5)}$ 다 형성 선종의 악성 전환율은 약 $6 \%$ 이며, 발병기간이 15 년 이상 될 때에는 $10 \%$ 까지 증가 될 수 있다는 보고 ${ }^{6)}$ 를 감안해 볼 때 조기 진단 및 치료의 중요성이 새삼 강 조된다. 따라서 비내시경과 전산화 단층촬영을 이용하여 종괴의 해부학적 경계부위를 확인한 후 조직생검을 실시 하여 확진해야한다.

감별해야 할 질환으로는 비강내 가장 많은 악성 종양 인 편평상피암, 양성종양인 반전성 유두종, 용종, 혈관 섬 유종외에도 다형성 선종내에 악성 세포들이 있는 암 전다형성 선종(carcinoma ex- pleomorphic adenoma)이 드물게 보고된다. ${ }^{5)}$

치료는 주위 정상 조직을 포함한 외과적 절제가 원칙 이다. 이러한 이유로 종물의 크기나 위치에 따라 내시경 하 비내 절제술, 측비절개술이나 안면부 노출술 등이 이 용될 수 있다. 비내시경의 장점은 수술시 외비접근술을 피할 수 있고 술 후 추적관찰에도 유용하나 본 예에서
와 같이 종괴가 전비강을 완전히 막고 있는 경우에는 종 괴의 후연을 정확히 파악할 수 없는 단점이 있다.

다형성 선종의 조직학적 특징은 상피세포가 점액성 기 질과 섞여 있는 형태인데, 주타액선에서 발생한 경우와 비교해 볼 때 비강에서 발생한 경우에는 세포 충실도가 훨씬 높다. 즉 타원형의 상피세포가 밀집배열을 하고 있 으며 점액성 기질은 더 적게 분포한다. 이러한 조직학적 특성 때문에 수술 중 점액성 기질이 수술부위에 퍼지는 경우가 적어져 비강내 다형성 선종의 재발률이 $10 \%$ 이 하인 것으로 알려져 있다. ${ }^{7)}$ 재발된 경우의 대부분은 수 술 후 첫 18 개월 동안 나타나지만, 50 년이 지난 후에도 나타날 수 있다. ${ }^{6)}$ 본 증례는 내시경 절제술 후 2년 5 개 월 동안 재발의 증거가 없었던 경우이나 향후 재발에 대 한 추적 관찰은 필요하다고 생각된다.

중심 단어 : 다형성 선종. 비강.

\section{REFERENCES}

1) Compago J, Wang RT. Intranasal mixed tumors (Pleomorphic adenomas). A clinicopathologic study of the 40 cases. Am J Clin Path 1977;68:213-8.

2) Suzuki K, Moribe K, Bara S. A rare case of pleomorphic adenoma of the lateral wall of the nasal cavity, with special reference of statiscal observation of pleomorphic adenoma of the nasal cavity in Japan. Nippon Jibiinkoka Gakkai Kaiho 1990;93:740-5.

3) Wakami S, Muraoka M, Nakai Y. Two cases of pleomorphic adenoma of the nasal cavity. Nippon Jibiinkoka Gakkai Kaiho 1996;99:38-45

4) Prager DA, Weiss MH, Buchalter WL, Jacobs M. Pleomorphic adenoma of the nasal cavity. Ann Otol Rhinol Laryngol 1991;100:600.

5) Cho KJ, El-Naggar AK, Mahanupab P, Luna MA, Batsakis JG. Carcinoma ex-pleomorphic adenoma of the nasal cavity: a report of two cases. J Laryngol Otol 1995;109: 677-9.

6) Unlu HH, Celik O, Demir MA, Eskiizmir G. Pleormorphic adenoma originated from the inferior nasal turbinate. Auris Nasus Larynx 2003;30;417-20.

7) Choi EC, Kim KM, Yoon JH, Cho NH, Park YY. Two cases of Benign Mixed Tumor on Nasal Septum. Korean J Otolaryngol 1989;32:1189-94. 